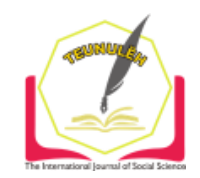

Jurnal Ilmiah Teunuleh

The International Journal of Social Sciences

Vol. 2, Issue. 2, June 2021

E-ISSN: $2746-4393$

\title{
PROCESS OF MANAGING INCOMING AND OUTGOING LETTER IN BAPPEDA NAGAN RAYA REGENCY
}

\author{
Ratna Dewi ${ }^{1}$; Muzakir ${ }^{2}$ \\ Faculty of Economic, Teuku Umar University, Meulaboh \\ ${ }^{2}$ muzakirzakir@utu.ac.id \\ corresponding author
}

\begin{abstract}
This study aims to determine how the process of managing incoming and outgoing letters at the Nagan Raya Bappeda Office. This study uses a qualitative descriptive method that draws whatever happens in the field without changing it. This study uses primary data and secondary data. Primary data were obtained from interviews with Bappeda Nagan Raya employees. While secondary data obtained from the web. Respondents from this study were 5 Bappeda employees. The results of this study indicate that the process of managing incoming and outgoing mail has not been carried out effectively. This is because the process of managing incoming and outgoing mail is still using manual procedures so that sometimes errors occur in the process.
\end{abstract}

Keyword: Management Process, Incoming and Outgoing Letter, BAPPEDA Nagan Raya

\section{A. Introduction}

The Work Unit of the Regional Development Planning Agency (BAPPEDA) of Nagan Raya Regency was formed based on the Decree of the Regent of Nagan Raya No. 6 of 2002, including several other agencies. Bappeda has the task of assisting the Regent in carrying out a government affair in the field of regional development planning which is the authority of the region and the assistance tasks given to the region. In accordance with what has been stipulated in the Regulation of the Regent of Nagan Raya number 75 of 2016 dated November 14, 2016, concerning the Position, Organizational Structure, Tasks, Functions and Work Procedures of the Regional Development Planning Agency of Nagan Raya Regency. 
The Office of the Regional Development Planning Agency of Nagan Raya Regency is a regional apparatus as an element of district government planning in the field of development planning which is led by a Head of the Agency and is responsible to the Regent through the Regency Regional Secretary. The Regional Development Planning Agency has the task of carrying out general government and development tasks in the field of developing development planning policies in accordance with applicable laws and regulations. As in the secretariat at the Nagan Raya Bappeda Office whose job is to receive incoming and outgoing letters.

Letter is a communication tool that is used to transmit recorded information from one field to another, either physically or via email. The function of letters is very large in the administrative field, precisely at the Bappeda Office of Nagan Raya Regency because letters act as carriers of information from messages that represent the author, using letters can shorten the distance, save time and energy, especially in incoming and outgoing letters in the Bappeda Secretariat. Nagan Raya Regency. In more detail, a letter is a written communication tool to convey messages to other parties who have special requirements, namely the use of paper, the use of models/forms, the use of codes and notation, use of distinctive language and inclusion of signatures. (Agus Sugiarto, 2015:2).

In each agency there are several activities to achieve a goal, and to realize the goals of the agency, several processes are needed in organizing to achieve the agency's goals properly. Kurniawan (2019) states that administration is a process of organizing resources so that work at any level can be carried out properly. In carrying out their duties as administra- tion in an agency, the administrator must do: 1. provide ideas to build an agency, 2. build an information system, 3. build a management system.

In the field of Secretariat, precisely the administration part in carrying out incoming and outgoing letters requires management because the recorded state is an essential component in an agency. Management in doing the work of incoming and outgoing letters, namely assembling the activities of recording, managing and delivering the letter to the place of interest. In any agency there is management of every job. It is the same in the world of technology. why management? Because to be more consistent and effective and efficient so that it can reach the desired goal.

At the Nagan Raya Regency Bappeda Office in managing the incoming and outgoing mail archives, a detailed examination is needed to avoid errors in filling in and out letters. For example, an error in filling in the date of the letter will cause problems in the agenda book for incoming and outgoing letters, but what sometimes happens is that 
the agenda book for incoming mail is scattered, delaying the work of employees who have to find the agenda book. And if the letter given from another agency is missing, this will cause work delays because employees have to look for the missing letter. This is of course not effective and efficient, therefore there is a need for data storage via a computer so that when a letter that is sent is lost it can be easily found and there is still something left.

Based on the background above, the writer can formulate the problem in this study, namely:

1. The process of managing letters is still manual so it is not effective and efficient.

The purpose of this research is to manage how the process of recording incoming and outgoing letters manually in the agenda book and to find out what deficiencies or inhibiting factors are faced by the Secretariat during the process of managing incoming and outgoing letters.

The results of this study are expected to be useful for agencies as input and consideration, especially at the Nagan Raya Bappeda Office. For the Secretariat, this research can be a reference to the process of managing incoming and outgoing letters in the agenda book. In addition, this research can add knowledge and insight on how to manage incoming and outgoing mail at the Nagan Raya Bappeda Office and also for the author himself.

\section{B. Research Methods}

This research is a research that uses a qualitative approach. A method that aims to analyze data based on facts found in the field which aims to explain the same problems that occur in actual events to direct conclusions. According to (Moleong, 2018), qualitative research is research that intends to understand the phenomena experienced by research subjects such as behavior, perception, motivation, action, etc., holistically and descriptively in the form of words and language on a special context that is natural and by utilizing natural methods. This research design uses a descriptive approach. According to (Arikunto, 2019) qualitative descriptive is giving predicates to accurate variables according to actual conditions.

The subjects of this research are employees who are directly involved with the management of incoming and outgoing mail, amounting to 5 people. The object of this research is the Bappeda Office of Nagan Raya Regency. Data collection techniques using interviews, observation and documentation. 


\section{Result and Discussion}

\section{Incoming Mail Management}

According to (Vidada, 2018) incoming letters are all letters received by a company/organization originating from other parties, be it individuals/organizations. Incoming letter is a continuous tool received from other agencies that is given to the company. Management of incoming mail is all activities that will be carried out when receiving incoming mail, and also in the management or settlement so that the letter is listed. Entry letters can be obtained from any institution and other agencies. Dwi Hartati (Hartati, 2018) according to Wursanto, management of incoming mail is the process of recording all types of letters received by other agencies and individuals, both those received by post (post office) and those received from couriers (mail senders) using a delivery book (expectation).

Figure 1 Incoming Mail Agenda

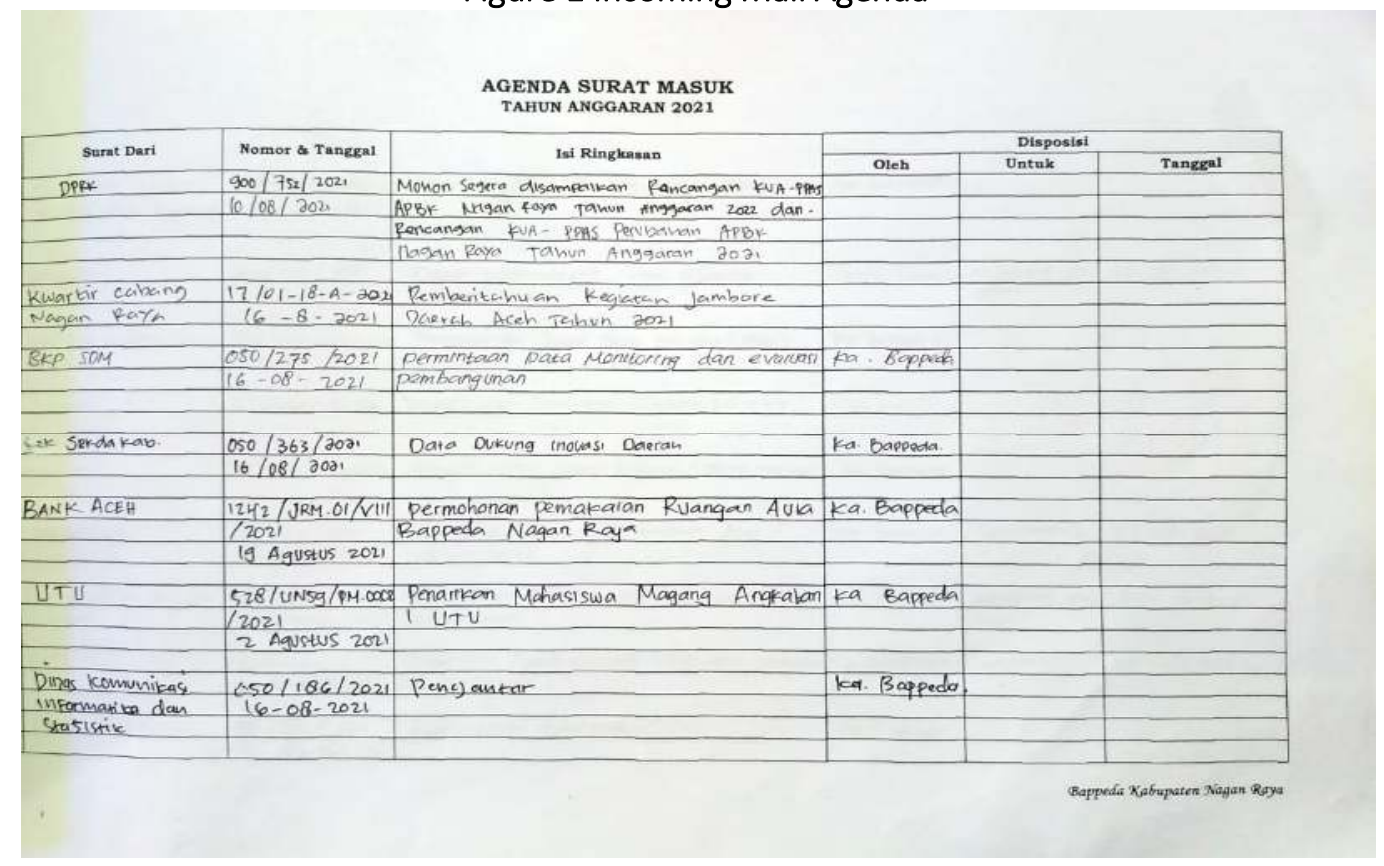

Figure 2 Disposition Sheet 


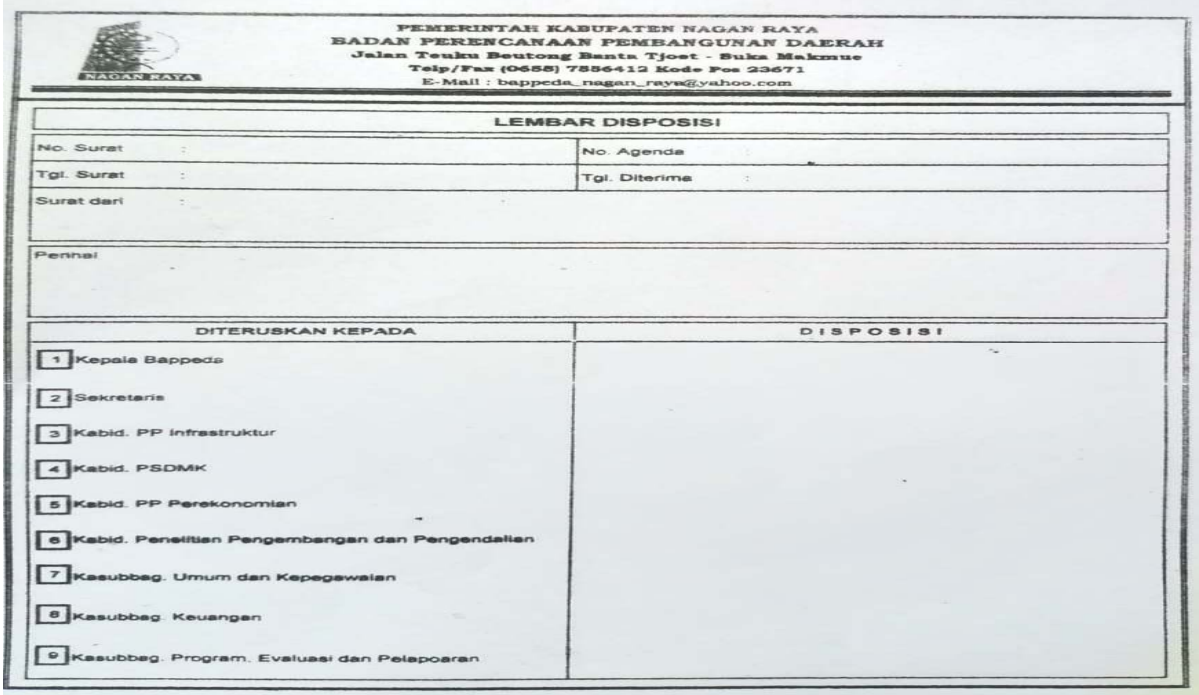

Data Source: Office of Bappeda Nagan Raya 2021

Receipt of Letters, receipt of letters is a job in the general or secretarial sub-section. In the management of receipt of incoming mail there are several good direct acceptance systems. For receipt of incoming mail, before being processed further, first check the number and address of the letter, fill in the initials and full name in the expectancy book. And give a letter to the picker.

Sorting Letters, in the management of incoming mail, it must be checked and the attachment to the letter of correct address must be examined. The letters are separated according to closed or secret letters. At the Bapeda Office of Nagan Raya Regency, incoming letters will be sorted according to the letter based on their classification.

Letter Defect, in the management of recording incoming mail, it is carried out in the incoming mail agenda book. Letter recording is an activity to record information about incoming mail, namely agenda number, letter number, letter date, subject, origin of the letter. In the process of recording letters, there are obstacles, namely in the recording of the agenda book, the letter is still manually which causes less accuracy in writing the information contained in the incoming letter, such as incorrectly numbering the letter, the date of the letter so that it will result in difficulty in finding information that is not clear in writing on the agenda book. .

Briefing, the process of directing incoming letters will first be received in the general administration section, then will be continued on the leadership section through 
the secretary first to convey the above letter to the processor through the processing administrative officer.

Storage, the storage of incoming mail is carried out in their respective fields, not stored in one place for the entire office archive. In storing incoming mail from directions that have been processed, it can be stored in a file cabinet in accordance with the filing staff system carried out by the general administration staff.

\section{Outgoing Mail Management}

Outgoing letter is a letter of a section sent within the company to be given to other agencies that already have a number, date, stamp signed by the leadership to be sent to other parties both in individuals and organizations. According to Wursanto in the Journal of Letter Management $(1,2013)$ Understanding letters are official letters made by organizations or companies that are sent or addressed to other parties outside the organization or company. In making the concept of outgoing letters, there is a mechanism for outgoing letters. In managing outgoing letters at the Bappeda Office of Nagan Raya Regency, there are several differences in managing outgoing letters directly, from managing letter concepts, checking, head ladder signs, numbering, recording, and distributing letters.

Figure 3 Outgoing Mail Agenda

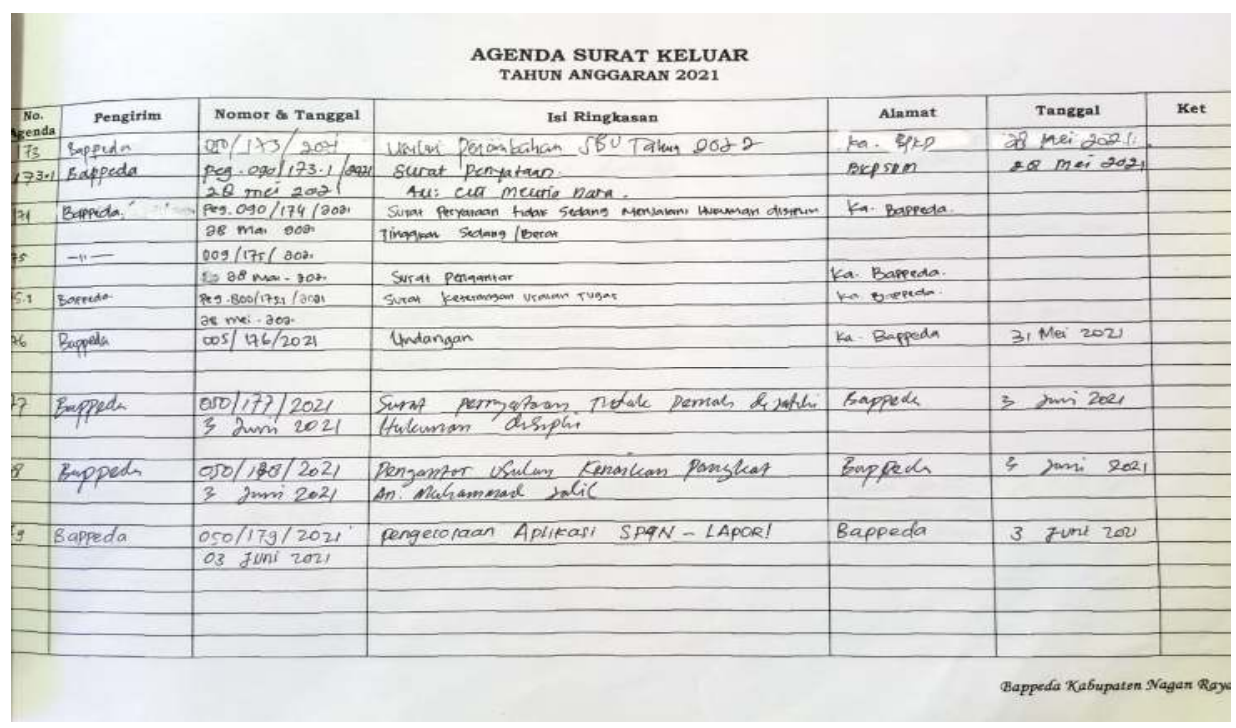

Data Source: Office of Bappeda Nagan Raya 2021

Management of outgoing letters, outgoing letters are letters addressed to other agencies in conveying information to reply to previous letters from agencies. Outgoing [458] 
letters to be sent to other agencies must be complete starting from letterhead which contains the name of the agency, complete address, telephone number, text or post box, wire address, organizational symbol, neck of the letter containing the date, number, attachments. This is the same as managing incoming mail. Outgoing letters can also be regarded as documents sent to a particular company/organization to convey important and accurate information in order to achieve common goals within an organization.

Conception, in drafting the outgoing letter can be carried out by the executor in the field that requires an outgoing letter or the leader himself, based on the disposition of the incoming letter from the leadership.

Typing Concepts, in drafting a letter, it is necessary to request approval from each field, starting from the sub-dept., head, secretary and then the head of Bappeda Nagan Raya. After that, the leader will check the sent letter, if there is an error in the letter, the letter will be returned to the secretariat to make up for deficiencies in the letter.

General and Personnel Sub-Section, after receiving approval from the leadership, the letter then goes to the secretariat to receive the letter number as well as the letter defect.

Storage, in storing outgoing mail can be done manually in fields that require letters. The storage of outgoing mail archives is the same as the storage of incoming mail, namely those stored by fields and not united in one place.

Distribution, after the completion of the letter which has been examined for completeness and has also received approval from the leadership, then the letter will be distributed according to the address to be addressed. And in sending letters out of the field, you can do the delivery yourself or ask for help from the General or Personnel subdivision staff to send the outgoing letter.

The mail management process is still manual so it is not effective and efficient.

As the development of information and communication technology affects the management of existing letters in a company. The management of letters is divided into two, incoming and outgoing letters, in the management of letters it is not far from the duties of a secretary. In general, in a mail management company, there is already a web or digital electronic based system in the system and application.

Therefore, it is necessary to do in the management of letters to be faster, there are arrangements in creating the effectiveness and efficiency of a company. Along with the times, mail management should not be used manually and change to a more modern 
system so that it can help complete letters more quickly. Therefore application-based management can reduce paper usage.

So in the explanation above that manual mail management has a drawback, namely the complexity of filing because of the large number of letters that are published every day and then the need for information. In addition, the general method will require a lot of paper and ink if it is used every day in making letters, it will require a special budget in supply.

\section{Conclusion}

In the process of managing incoming and outgoing mail, it must be effective and efficient in order to achieve all the main tasks, the implementation of the objectives of a program that is fast and timely in obtaining perfect results. Therefore, if something goes quickly in accordance with the plan, it will get good management, it can be said to be effective.

\section{Bibliography}

Arikunto, S. (2019). Prosedur Penelitian: Suatu Pendekatan Praktik. Jakarta: Rineka Cipta.

Azizah, N. F., \& Kuswantoro, A. (2021). Pengelolaan Surat Masuk dan Surat Keluar. Economic Education Analysis Journal, 10(1), 65-81. doi:10.15294/eeaj

Bappeda. (2020). Laporan Akuntabilitas dan Kinerja Instansi Pemerintah (LAKIP) Suka Makmue, Nagan Raya. Nagan Raya: Pemerintah Daerah Nagan Raya.

Charis, M. (2009). Sistem Informasi Pengelolaan Surat Masuk dan Keluar Dengan Visual Foxpro 8.0. Tatal-Jurnal Teknik, 5(1), 22-40.

Hartati, D. (2018). Etika Profesi (Untuk SMK/MAK Kelas X. Semarang: Erlangga.

Hartika, M. B. (2019). Pengelolaan Surat Masuk dan Keluar Bagian Kesekretariatan Dinas Pariwisata Dan Kebudayaan Kabupaten Jember. Jember: Universitas Jember. Retrieved from http://repository.unej.ac.id/handle/123456789/100201

Mardiyati, S. (2020, Maret). Sistem Pengelolaan Data Surat Masuk dan Surat Keluar Kelurahan Curug. Jurnal Inovasi Informatika, 5(1), 11-23. doi:10.51170/jii

Moleong, J. L. (2018). Metodologi Penelitian Kualitatif (XXXVIII ed.). Bandung: PT. Remaja Rosdakarya.

Nur'aini, \& Halawa, K. (2019). Pengelolaan Surat Masuk dan Surat Keluar di Perpustakaan STIPAP Medan. Iqra': Jurnal Perpustakaan dan Informasi, 13(2), 22-34. doi:10.30829/iqra 
Process of Managing Incoming and Outgoing Letter in BAPPEDA Nagan Raya Regency

Utomo, K. P., \& Daryoto. (2018, Maret). Analisis Sistem Proses Pengelolaan Surat Masuk dan Keluar di Pemerintahan Kota Bekasi (Studi Kasus Pada Bagian Bina Ekonomi, Pembangunan dan Bina Ketahanan Pangan Sekretariat Daerah Kota Bekasi). Jurnal Administrasi dan Kesekretarisan, 3(1), 10-19.

Wulandari, A. (2012). Prosedur Surat Masuk dan Surat Keluar pada Bagian Umum Setda Pemerintahan Kota Surakarta. Surakarta: Universitas Sebelas Maret. Retrieved from https://digilib.uns.ac.id/dokumen 